\title{
Effect of pre-treatment and drying method on physico-chemical properties and dry fractionation behaviour of mealworm larvae (Tenebrio molitor L.)
}

\author{
Benedict Purschke $^{1}\left(\mathbb{D} \cdot\right.$ Henrik Brüggen $^{1} \cdot$ Rafaela Scheibelberger $^{1} \cdot$ Henry Jäger $^{1}$
}

Received: 19 April 2017 / Revised: 29 June 2017 / Accepted: 14 July 2017 / Published online: 27 July 2017

(C) The Author(s) 2017. This article is an open access publication

\begin{abstract}
Edible insects have emerged as an alternative source for feed and food. Fractionation is considered as a promising strategy to produce standardised insect-based intermediates to augment industrial applicability and consumer acceptance. So far, mainly wet fractionation techniques were studied to separate insect components and concentrate protein. This study investigated a dry fractionation approach to yield protein-enriched and differently composed fractions of mealworm larvae (Tenebrio molitor). The influence of post-harvest procedures including different pre-treatments (blanching, freezing, etc.), drying methods (oven drying, fluidized bed drying, freeze-drying, etc.), and defatting on physico-chemical properties of the larvae were studied. Furthermore, the impact of pre-processing on disintegration of larvae during roller milling was investigated via sieve classification. Applied post-harvest process chain significantly affected the colour, dimensions, apparent density, and hardness of dried larvae with an impact on fractionation behaviour and characteristics of the obtained fractions. Drying at elevated temperatures caused pronounced darkening and shrinkage due to browning reactions and tissue collapse. Mechanical properties were affected as well leading to heterogeneous particle size distributions after milling and sieving. A large fraction of particles $<500 \mu \mathrm{m}$ was determined for samples exhibiting low mechanical hardness such as freeze-dried and defatted larvae. Significant differences in macro-nutrient composition of the sieving fractions were found deviating in chitin (3.6-16.1\%db),
\end{abstract}

Benedict Purschke

benedict.purschke@boku.ac.at

1 Department of Food Science and Technology, Institute of Food Technology, University of Natural Resources and Life Sciences (BOKU), Muthgasse 18, 1190 Vienna, Austria protein $(52.5-58.2 \% \mathrm{db})$ and fat $(21.4-26.6 \% \mathrm{db})$ content. Highest protein recovery of max $72 \%$ was determined in the particle size fraction 500-1000 $\mu \mathrm{m}$. Concluding, these results provide insights into physico-chemical characteristics of mealworms affected by pre-treatment and drying. The potential of dry fractionation techniques for protein enrichment and delivery of a variety of differently composed mealworm fractions was demonstrated and may provide an interesting potential to optimize water and energy consumption during insect fractionation.

Keywords Edible insects - Mealworm larvae . Post-harvest processing $\cdot$ Dry fractionation $\cdot$ Sieve classification $\cdot$ Protein enrichment

\section{Introduction}

In the last years, edible insects have received wide attention as an alternative source of animal-derived protein and caloric energy for the use in the feed and food value chain. Driven by the predicted growth of the global population to about 9 billion people in 2050 and the increasing future demand for high-quality protein for human alimentation and livestock breeding, insects are extensively discussed as a promising alternative to common protein sources such as soy, meat and fishmeal [1-3]. In addition, insects may have the potential to be used for the valorization of food by-products and waste [4, 5]. Compositional data of edible insects and products thereof have indicated auspicious crude protein and fat contents of up to $77 \%$ on dry base highly dependent on the regarded order, species, metamorphic stage, diet, and habitat [6-8]. Furthermore, insects` biological properties such as high fecundity, multivoltine life cycle, high feed conversion ratio, 
omnivorous diet, low substrate, water and space requirements highlight the potential of edible insects to contribute to global food security either via feed or directly as food [9]. However, mass rearing of insects together with industrial processing concepts for the recovery of valuable insect fractions will be a prerequisite for an efficient use in the feed and food value chain. Energy and water consumption during the post-harvest processing of insects is one major impact factor when evaluating the sustainability of this raw material for use in the food and feed chain. Therefore, alternatives to the conventional wet processing concepts with reduced water and energy requirements are required.

Beside other insect species, the larval stage of the yellow mealworm beetle (Tenebrio molitor, Coleoptera) hereinafter referred to as TML-is considered to be a suitable candidate for large scale production and integration in European food and feed industry [1, 10]. Industrial-scale breeding expertise of TML already exists as they are commercially reared in several countries as feed for pets and zoo animals or even for human consumption [11]. In China for example, TML is the most commonly cultivated insect with a throughput of thousands of tons per year [11]. Promising contents of crude protein and fat of up to 60 and $40 \%$, respectively, were reported for TML on dry base $[12,13]$. The protein quality in terms of essential amino acid content satisfies the recommendation for adult's requirement by the WHO [6]. First, studies on techno-functional properties of TML protein fractions revealed promising protein solubilities between 60 and $100 \%$ at alkaline $\mathrm{pH}$ depending on the applied pre-treatment, extraction procedure and fractions' composition [14-17].

The industrial use of insect-derived ingredients such as protein, fat or chitin requires an efficient recovery followed by the purification of standardised fractions to explore a wide range of potential applications. In addition, consumer acceptance towards the consumption of edible insects is one major concern in Western countries as entomophagy is not rooted in the traditional diets and insects are mostly rejected as disgusting, unclean and risk associated with regard to food contamination [18]. Nevertheless, several consumer studies have already shown that western consumers`willingness to eat edible insects increases when served in an invisible form, thus, transformed into known food items by conventional food processing [18-21]. Hence, insects are more likely to be used and consumed in a processed form enhancing product functionality, stability, safety and appearance. Consequently, there is a need for the development of tailored post-harvest processes especially fractionation concepts to establish high-quality, nutritious, safe and shelf-stable insect-based products or intermediates which can be further incorporated into common food items [22].
Wet fractionation techniques are mainstream technology for the production of plant-derived protein concentrates and isolates achieving purities of $>90 \%$ [23]. To date, mainly approaches in analogy to those wet procedures were investigated to separate and purify the major insect components - chitin, fat, and protein - while the latter mostly represented the target fraction. Wet fractionation processes were studied for several edible insect species, among others, TML [15, 16, 24], honey bee [25, 26], and Mexican fruit fly larvae [27]. Various production steps such as solvent defatting, aqueous extraction at harsh $\mathrm{pH}$ conditions and elevated temperature, mechanical separation of insoluble matter, isoelectric precipitation, and drying are often involved and accompanied by detrimental effects on native protein functionality and high water and energy consumption [23].

Dry fractionation, on the other hand, can provide a promising, energy-efficient alternative for the production of protein-enriched, functional fractions or protein concentrates with preserved native functionality but lower purity $[23,28]$. Such processes are long established and successfully applied in cereal technology for the separation of the endosperm and bran fraction in flour production using different milling and classification techniques. Furthermore, several studies reported the successful use of dry fractionation for the separation of pulses such as lentil, bean, and pea into protein-rich and protein-depleted fractions [28-30]. In analogy to the bran fraction of cereal kernels, insects and thus TML are covered by an exoskeleton mainly composed of the polysaccharide chitin which encloses the inner tissue [31]. Hence, dry fractionation can be a suitable tool for edible insect fractionation and production of protein-enriched flours or concentrates by depleting the chitin fraction. Furthermore, different pre-treatments prior to dry fractionation such as blanching, drying, defatting and conditioning will affect the processing behaviour of the raw material during dry fractionation. This is an already established technique to modify mechanical properties (elasticity and plasticity) of cereal kernel constituents and crops by adding water to tailor their disintegration and fractionation behaviour [32, 33].

To the best of our knowledge, scientific studies on dry fractionation of mealworm or other edible insect species are not available yet. Consequently, the objective of this study was to evaluate the feasibility of a dry fractionation procedure based on roller milling and sieve classification for the production of protein-enriched TML fractions as an alternative to conventional wet fractionation approaches. In addition, the effect of several commonly applied postharvest processing steps for edible insects such as blanching, freezing, drying, and defatting on the physico-chemical properties of the larvae and the fractionation behaviour was studied as well. 


\section{Materials and methods}

\section{Raw material and chemicals}

TML were purchased alive from a pet food vendor (Dragon Terraristik, Duisburg, Germany). Substrate residues, frass, and other impurities were separated from the larvae by sieving through $3 \mathrm{~mm}$ screening size. Afterwards, TML were stored for several hours at $3{ }^{\circ} \mathrm{C}$ in a cooling chamber to anesthetize them prior processing.
For supercritical fluid defatting of the larvae, carbon dioxide with a purity $\geq 99.5 \%$ (CE290, Linde AG, Pullach, Germany) was used. Other reagents used for analytical purposes were of analytical grade if not stated otherwise.

\section{Sample preparation and processing}

Figure 1 presents an overview of the process combinations applied. Prior to dry fractionation, the larvae were subjected to various post-harvest processing procedures. Different thermal pre-treatments such as blanching and

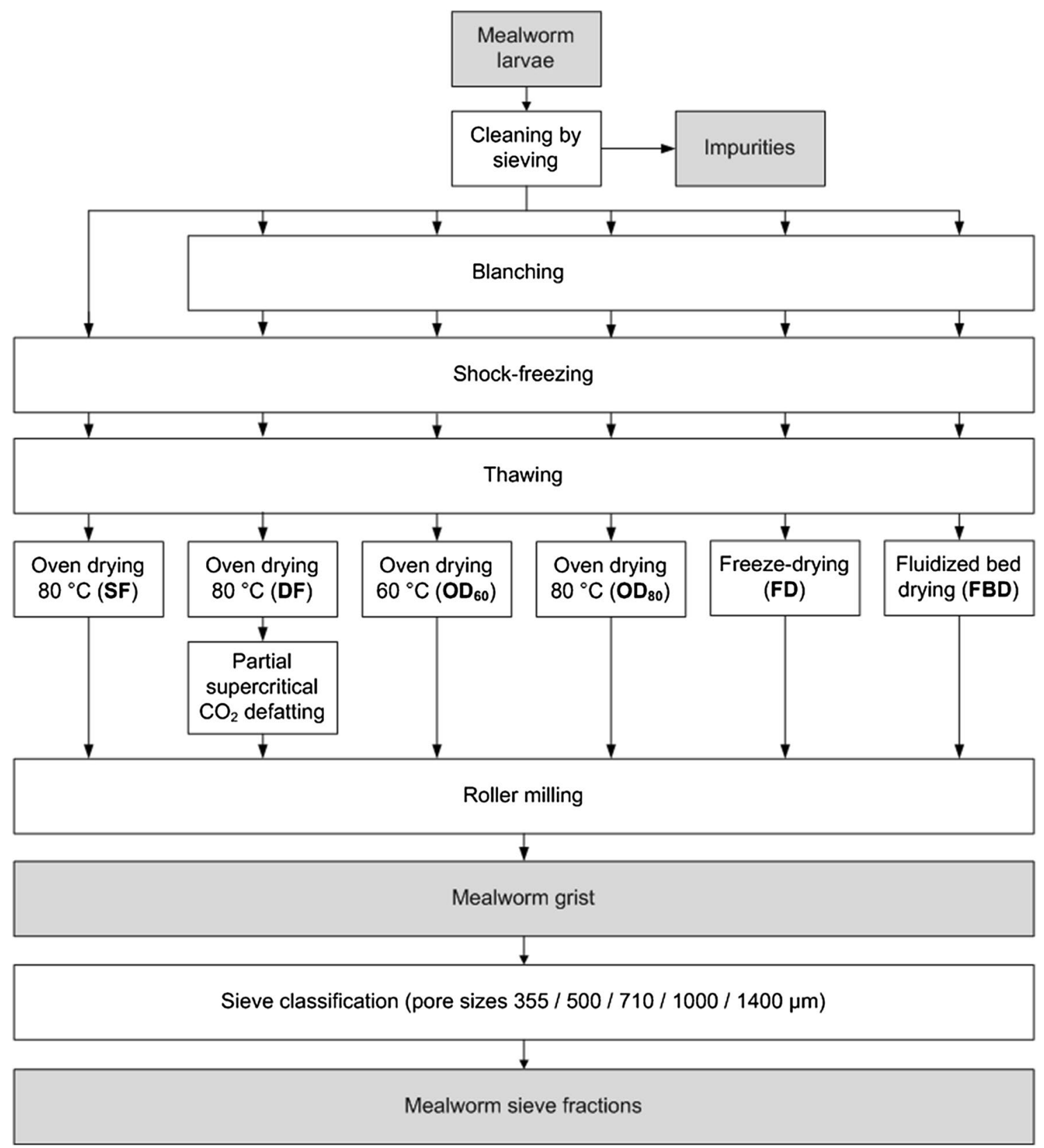

Fig. 1 Scheme of the processing procedures subjected to the different mealworm larvae samples. Sample IDs are given in bold letters 
shock-freezing, an additional defatting step via supercritical $\mathrm{CO}_{2}$ extraction, and several drying techniques such as convectional oven drying, freeze-drying, and fluidized bed drying were combined. The detailed descriptions of the single processing steps are given in the following subchapters. The same processing procedure was applied to three independent samples resulting in triplicate.

\section{Pre-treatment}

Larvae were blanched for $10 \mathrm{~min}$ in boiling water at a larvae-water ratio of $1: 12(\mathrm{w} / \mathrm{w})$ to prevent water temperature drop. Afterwards, excess water was removed and larvae were individually quick frozen at $-38^{\circ} \mathrm{C}$ for about 20 min in a shock freezer (F101L, Sagi, Ascoli Piceno, Italy) to maintain pourability and subsequently stored at $-30{ }^{\circ} \mathrm{C}$ until further use. Before hot air drying, frozen larvae were evenly spread on trays in a thin layer and thawed for $1 \mathrm{~h}$ at room temperature.

\section{Drying}

Convectional hot air drying was realised using a circulating air oven (Memmert, Schwabach, Germany) at ventilation stage 2. Convection oven was loaded with $1.73 \mathrm{~kg}$ thawed larvae. The larvae were dried to constant mass for a period of 24 and $7 \mathrm{~h}$ at 60 and $80{ }^{\circ} \mathrm{C}$, respectively. After drying, larvae were cooled for $2 \mathrm{~h}$ to room temperature, sealed airtight in polyethylene bags to prevent remoistening and stored at room temperature until further use.

Freeze-drying of larvae was performed using a benchtop lab scale freeze-dryer (FreeZone 6, Labconco, Kansas City, USA) at 0.2 mbar. Drying chamber was loaded with $1.73 \mathrm{~kg}$ of frozen larvae. During a drying period of $48 \mathrm{~h}$, larvae were dried to constant mass. Afterwards, larvae were sealed airtight in polyethylene bags and stored at room temperature until further use.

Fluidized bed drying of larvae was conducted using a pilot scale fluidized bed drying system (A-WT 25, Ammag, Gunskirchen, Austria). Process parameters were set as follows: Bed temperature $60{ }^{\circ} \mathrm{C}$; air outlet temperature $55^{\circ} \mathrm{C}$; differential pressure bed 15 bar; differential pressure filter -1.3 bar; air flow $500 \mathrm{~m}^{3} \mathrm{~h}^{-1}$. Drying chamber was loaded with $1.73 \mathrm{~kg}$ of larvae. The larvae were dried until constant mass for a drying period of $2 \mathrm{~h}$. After drying, larvae were cooled down for $2 \mathrm{~h}$ to room temperature and stored at room temperature in airtight polyethylene bags until further use.

\section{Partial defatting by supercritical carbon dioxide extraction}

Partial defatting of dried larvae was performed using a 500 bar pilot scale supercritical $\mathrm{CO}_{2}$ extraction unit equipped with a $2 \mathrm{~L}$ extractor, two-stage separation, and solvent recovery system (Natex Prozesstechnologie, Ternitz, Austria) as described elsewhere [34]. Extraction parameters were chosen according to the study of Purschke et al. [35] and set to $400 \mathrm{bar}, 45^{\circ} \mathrm{C}$, and $20 \mathrm{~kg}$ of $\mathrm{CO}_{2} / \mathrm{h}$. The extractor was charged with $250 \mathrm{~g}$ of dried larvae. Extraction was performed in analogy to Ruttarattanamongkol et al. [34] with small modifications. Extracted oil was collected at the first separator every $15 \mathrm{~min}$ for the total extraction time of $6 \mathrm{~h}$. Defatted larvae were stored airtight in polyethylene bags at room temperature.

\section{Preparation of larval fractions}

Dried larvae were ground using a pilot scale roller mill (Kropfitschmühle, Klagenfurt, Austria) equipped with two corrugated rollers and a milling gap of $0.3 \mathrm{~mm}$. Subsequently, the resulting mealworm larvae grist were fractionated by size via sieve analysis according to ICC recommendation No. 207 [36] with small modifications. Test sieves with mesh apertures of $355,500,710,1000$, and $1400 \mu \mathrm{m}$ and a mechanical sifting system (EML 200, Haver \& Boecker, Oelde, Germany) were used for the fractionation. $150 \mathrm{~g}$ of larval grist were classified per run for a period of 20 min using intensity setting stage 4 .

\section{Chemical composition of larvae and larval fractions}

The dry matter content was determined by oven drying method at $105 \pm 3{ }^{\circ} \mathrm{C}$ based on AOAC 950.46 [37]. After solvent extraction with petroleum ether (b.p. $40-60{ }^{\circ} \mathrm{C}$ ) in a Soxhlet extractor, the crude fat content was analysed gravimetrically based on the ICC standard method No. 136 [38]. In addition, the ash content was analysed according to the AOAC 923.03 [37] via muffle furnace method. The chitin-derived nitrogen content was analysed as described elsewhere [39] via alkaline hydrolysis and subsequent total nitrogen determination of the dried residue using the Kjeldahl method according to AOAC 928.08 [37]. Chitin content was calculated using the nitrogen conversion factor 14.5 [40]. The total nitrogen content was analysed using the Kjeldahl method according to AOAC 928.08 [37]. After subtraction of the chitin-derived nitrogen content, the crude protein content was calculated using the nitrogen conversion factor $(\mathrm{N})$ of 6.25 . All determinations were done in triplicate.

\section{Physico-chemical properties of larvae and larval grist}

\section{Colour and size}

Colour of mealworm larvae was determined using a noncontact digital imaging system (DigiEye, VeriVide Limited, 
Enderby, Leicester, UK) equipped with a high resolution digital camera (D90, Nikon, Tokyo, Japan), auto-focus zoom lens (AF-S DX NIKKOR 18-105 mm, Nikon, Tokyo, Japan) and the corresponding data evaluation software (DigiEye 2.7.2.0, VeriVide Limited, Enderby, Leicester, UK). The imaging system was calibrated using the provided white and colour standards. Pictures of about 100 larvae per sample were taken on a white background. For colour analysis, background of the pictures was removed and colour of the larvae were determined within the CIE $L^{*} a^{*} b$ colour space. Colour measurements were done in triplicate. Colour difference $\left(\Delta E_{\mathrm{Lab}}^{*}\right)$ was calculated according to Eq. 1 using the raw, untreated mealworm as reference (ref).

$$
\Delta E_{\mathrm{Lab}}^{*}=\sqrt{\left(L_{\mathrm{ref}}^{*}-L_{1}^{*}\right)^{2}-\left(a_{\mathrm{ref}}^{*}-a_{1}^{*}\right)^{2}-\left(b_{\mathrm{ref}}^{*}-b_{1}^{*}\right)^{2}}
$$

Size parameters of the dried larvae were analysed using the pictures taken for the colour analysis. A scale bar was embedded in each picture. Pictures were evaluated using image analysis software (cellSens Dimensions 1.12, Olympus, Tokyo, Japan). Software measuring tool was calibrated using the scale bar. Length and diameter at the widest part of larvae were analysed. At least 450 larvae of each sample were investigated for size analysis.

\section{Hardness and apparent density}

Mechanical properties of the dried larvae in terms of hardness were determined using a TA.XT Plus Texture Analyser (Stable Micro Systems, Haslemere, Surrey, UK), equipped with a back extrusion rig and a compression disc of $45 \mathrm{~mm}$ diameter attached to an extension bar using $50-\mathrm{kg}$ load cell. Back extrusion container (50 $\mathrm{mm}$ diameter) was filled to a defined level $(4 \mathrm{~cm})$ with the sample. The force-displacement profiles were recorded and maximum compression force $\left(F_{\max }\right)$ in penetration was obtained as a measure of larvae hardness. The test was conducted at a pretest speed of $3.0 \mathrm{~mm} / \mathrm{s}$, test speed of $2.0 \mathrm{~mm} / \mathrm{s}$ and a trigger point of $5 \mathrm{~g}$. Samples were penetrated to a depth of $15 \mathrm{~mm}$.

The apparent (bulk) density of whole larvae and larval grist was determined based on ISO 7971-1:2009 using a hectolitre scale (Schopper. Leipzig, Germany) equipped with a measuring cylinder of a defined volume of $250 \mathrm{ml}$. Measuring cylinder was filled with the sample via a standardised filling hopper. Finally, the weight of filled cylinder was determined gravimetrically to determine the apparent density.

\section{Particle size distribution of larval grist}

Particle size distribution of the ground mealworm grist was determined using sieve analysis according to ICC recommendation No. 207 [36] as already described in chapter 2.3.
The weight of each test sieve and bottom pan was determined before and after sieving with $0.01 \mathrm{~g}$ accuracy. Sieve analysis was conducted in sixfold replication.

\section{Statistical analysis}

Statistical analyses were carried out using Statgraphics Centurion XVI (Statpoint Technologies Inc., Warrenton/ USA). Data are expressed as mean \pm standard deviation (SD) of the performed replications. Data were subjected to one-way analysis of variances (ANOVA), and means were generated and adjusted using LSD post hoc test. Unless otherwise stated, a 95\% confidence level (statistical significance at $p \leq 0.05$ ) was considered.

\section{Results and discussion}

\section{Chemical composition of larvae}

Moisture content of fresh and blanched TML was $68.36 \pm 0.81 \%$ and $73.98 \pm 0.06 \%$, respectively. Based on dry matter, fresh mealworm larvae were composed of $53.26 \pm 0.26 \%$ crude protein, $22.72 \pm 1.60 \%$ crude fat, $12.79 \pm 0.19 \%$ chitin, and $4.50 \pm 0.09 \%$ ash. Values are comparable with previous results reporting moisture contents of $58-70 \%$, crude protein contents of $48-60 \% \mathrm{db}$, crude fat contents of $21-40 \% \mathrm{db}$, fibre/chitin contents between 4 and $15 \% \mathrm{db}$, and ash contents in the range of $3-7 \% \mathrm{db}$, respectively $[6,12,13,35,41]$. The large heterogeneity of nutrient composition-even in the same species and metamorphic stage - can be ascribed to different diet, instar, origin, season, and gut content [7]. Blanching did not significantly influence the composition of macronutrients as the blanched larvae contained $52.97 \pm 0.31 \% \mathrm{db}$ crude protein, $22.14 \pm 0.22 \% \mathrm{db}$ crude fat, $12.76 \pm 0.25 \% \mathrm{db}$ chitin, and $4.36 \pm 0.13 \% \mathrm{db}$ ash. This is in accordance to the results of Azzollini et al. [42] which found no significant changes in proximate composition of TML after blanching for $3 \mathrm{~min}$ in boiling water. Composition of larvae after partly defatting via supercritical $\mathrm{CO}_{2}$ extraction changed as follows: $61.06 \pm 0.35 \% \mathrm{db}$ crude protein, $9.47 \pm 0.24 \% \mathrm{db}$ crude fat, $14.74 \pm 0.21 \% \mathrm{db}$ chitin, and $5.02 \pm 0.15 \% \mathrm{db}$ ash.

\section{Physico-chemical properties of whole larvae}

Table 1 presents the physico-chemical characteristics of the whole larvae after application of the different pretreatment/drying combinations. Larval colour was shown to be altered by processing demonstrated by the colour difference $\Delta E_{\mathrm{Lab}}^{*}$. According to Adekunte et al. [43], differences in perceivable colour can be classified as "very distinct" $(\Delta E>3)$, "distinct" $(1.5<\Delta E<3)$ and "small 
Table 1 Physico-chemical properties of raw and differently processed whole mealworm larvae: Colour $\left(L^{*} a^{*} b\right)$, colour difference $\left(\Delta E_{\mathrm{Lab}}^{*}\right)$, apparent density $(\rho)$ and hardness $\left(F_{\max }\right)$

\begin{tabular}{|c|c|c|c|c|c|c|}
\hline \multirow[t]{2}{*}{ Sample ID } & \multicolumn{3}{|l|}{ Colour } & \multirow[t]{2}{*}{$\Delta E_{\mathrm{Lab}}^{*}$} & \multirow[t]{2}{*}{$\rho\left(\mathrm{g} / \mathrm{dm}^{3}\right)$} & \multirow[t]{2}{*}{$F_{\max }(\mathrm{N})$} \\
\hline & $L^{*}$ & $a^{*}$ & $b^{*}$ & & & \\
\hline Raw material & $54.74 \pm 1.10^{\mathrm{e}}$ & $9.69 \pm 0.22^{\mathrm{d}}$ & $23.82 \pm 0.72^{\mathrm{e}}$ & - & - & - \\
\hline SF & $39.51 \pm 1.36^{\mathrm{a}}$ & $6.90 \pm 0.71^{\mathrm{a}}$ & $12.78 \pm 1.17^{\mathrm{a}}$ & 19.01 & $236.34 \pm 2.97^{f}$ & $115.33 \pm 17.70^{c}$ \\
\hline $\mathrm{DF}$ & $56.03 \pm 1.39^{\mathrm{e}}$ & $8.58 \pm 0.23^{c}$ & $23.72 \pm 0.41^{\mathrm{e}}$ & 1.71 & $172.62 \pm 1.86^{\mathrm{b}}$ & $92.24 \pm 6.14^{b}$ \\
\hline $\mathrm{OD}_{60}$ & $48.01 \pm 1.26^{\mathrm{c}}$ & $7.93 \pm 0.59^{b}$ & $17.87 \pm 1.40^{c}$ & 9.15 & $209.84 \pm 2.26^{\mathrm{d}}$ & $104.12 \pm 8.50^{b c}$ \\
\hline $\mathrm{OD}_{80}$ & $49.39 \pm 1.52^{\mathrm{d}}$ & $7.47 \pm 0.49^{b}$ & $16.29 \pm 0.93^{b}$ & 9.49 & $220.77 \pm 2.33^{\mathrm{e}}$ & $149.02 \pm 9.91^{\mathrm{d}}$ \\
\hline FD & $59.73 \pm 1.38^{f}$ & $8.94 \pm 0.43^{c}$ & $25.37 \pm 1.25^{\mathrm{f}}$ & 5.28 & $135.58 \pm 1.51^{\mathrm{a}}$ & $65.62 \pm 16.21^{\mathrm{a}}$ \\
\hline FBD & $46.61 \pm 1.13^{b}$ & $8.76 \pm 0.44^{c}$ & $19.19 \pm 1.06^{\mathrm{d}}$ & 9.39 & $204.57 \pm 2.28^{c}$ & $105.18 \pm 10.50^{\mathrm{bc}}$ \\
\hline
\end{tabular}

Values are means \pm SD of at least triplicate measurements. Different superscripts within one column indicate significant differences ( $\mathrm{p} \leq 0.05$; one-way ANOVA, LSD post hoc test)
Fig. 2 Larvae length distribution (top) and diameter distribution (bottom) of the raw and differently processed whole dried mealworm larvae. Asterisks above one group indicate significant differences $(p \leq 0.05$; one-way ANOVA, LSD post hoc test) between samples
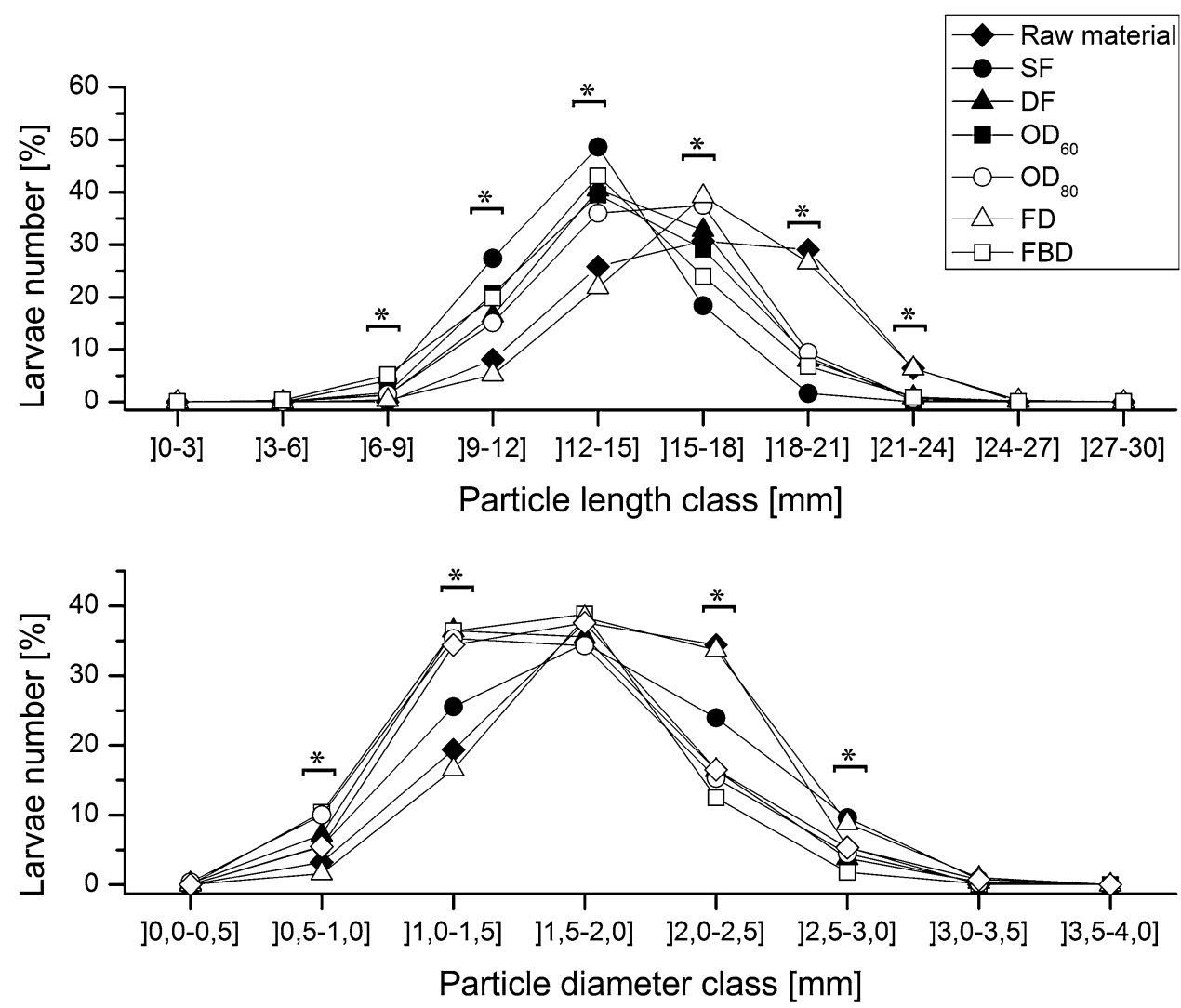

difference" $(\Delta E<1.5)$. Thus, all process combination except the one including defatting DF $(\Delta E=1.7)$ caused "very distinct" differences of larval colour in comparison to the reference. Maximal colour deviation indicated by lowest lightness $\left(L^{*}\right)$ and yellowness $\left(b^{*}\right)$ was observed for SF (unblanched and air dried at $80{ }^{\circ} \mathrm{C}$ ) due to the combination of enzymatic and non-enzymatic browning resulting in the formation of brown pigments as similarly reported by Azzollini et al. [42]. Procedures combining blanching and oven or fluidized bed drying induced a minor degree of browning due to inactivation of browning enzymes such as polyphenoloxidase, which was shown to loose activity after 2 min at $60{ }^{\circ} \mathrm{C}$ in crustaceans [44]. Initial colour was best conserved in case of FD (blanched and freeze-dried) and DF (blanched, dried at $80{ }^{\circ} \mathrm{C}$, and defatted). This can be ascribed to the omission of thermal browning reactions in freeze-dried larvae and co-extraction of brown lipophilic melanoidins during defatting previously observed by Jeon et al. [45] for hexane-extracted oil of roasted mealworms, respectively.

Dimensions of larvae in terms of length and diameter were significantly affected by the processing route as well. The results are illustrated in Fig. 2. Freeze-drying (FD) was shown to preserve the original larval morphology of the best resulting in similar length and diameter distributions in comparison to the untreated raw larvae. This is a known 
behaviour as freeze-drying prevents undesirable shrinkage and produces dried goods with high porosity in comparison to conventional thermal drying [46]. Application of oven and fluidized bed drying, respectively, led to shrivelled larvae exhibiting smaller length and diameter due to tissue collapse and loss of porosity [47].

This observation was supported by the results of apparent density determination (Table 1). Density of thermally dried larvae (SF, $\left.\mathrm{OD}_{60}, \mathrm{OD}_{80}, \mathrm{FDB}\right)$ was shown to be significantly higher due to shrinkage and loss of volume and porosity in comparison to the freeze-dried larvae which show the lowest density of all samples. The increment of drying temperature from $60{ }^{\circ} \mathrm{C}\left(\mathrm{OD}_{60}, \mathrm{FBD}\right)$ to $80{ }^{\circ} \mathrm{C}$ $\left(\mathrm{SF}, \mathrm{OD}_{80}\right)$ resulted in an increase in density probably due to higher volume shrinkage and tissue collapse. Similar behaviour was previously observed for hot air and superheated steam dried shrimps which are phylogenetically related to insects $[48,49]$. In case of DF, the effect of oven drying at $80{ }^{\circ} \mathrm{C}$ on apparent density was superimposed by the subsequent defatting step and resulted in intermediate density value. The solubilisation and removal of the larval fat by supercritical $\mathrm{CO}_{2}$ led to the generation of voids and a porous-like structure. This mechanism is also used in supercritical drying of biomaterial to maintain porosity of the dried goods [50].

Mechanical hardness determined via texture analysis was found to correlate well with the density and thus, porosity of the larvae. The low-density, porous structure of freeze-dried larvae led to a significant lower compression force required for deformation in comparison to the shrunk, compacted structure of thermally dried samples. Furthermore, as previously reported for dried mushrooms, an increment of drying temperature from $60{ }^{\circ} \mathrm{C}\left(\mathrm{OD}_{60}\right.$, FBD) to $80{ }^{\circ} \mathrm{C}\left(\mathrm{SF}, \mathrm{OD}_{80}\right)$ resulted in an increase in hardness probably due to more pronounced collapse of capillary voids in the larvae [51]. In analogy to the density results, DF showed an intermediate mechanical hardness due to the partly porous structure after supercritical $\mathrm{CO}_{2}$ defatting [50].

\section{Dry fractionation}

Figure 3 and Table 2 present the results of the particle size determination of the mealworm grist after defined roller milling of the differently processed larvae assayed via sieve analysis. Applied processing prior milling was found to affect the disintegration properties of the dried larvae, and thus, the particle size distribution of the mealworm grist. Proportion of small particles $<500 \mu \mathrm{m}$ was significantly lower after milling of larvae exhibiting a high mechanical hardness (SF, $\left.\mathrm{OD}_{60}, \mathrm{OD}_{80}, \mathrm{FDB}\right)$ and vice versa. Grist of samples with lower larval hardness (FD, DF) contained a considerably higher proportion of fine particles fractions $(<500 \mu \mathrm{m})$. This is in accordance to the results of Blandino et al. [52] who showed a significant positive correlation $(p \leq 0.05)$ between the breaking force of whole maize kernels and the coarse/fines ratio of maize flour after milling. Higher kernel hardness resulted in a higher ratio of coarse $(700-2000 \mu \mathrm{m})$ to fine material $(<500 \mu \mathrm{m})$. Similar observations were made by Pomeranz et al. [53] correlating increasing Stenvert hardness of corn kernels to higher coarse material mass fraction. The decisively high proportion of particles $<355 \mu \mathrm{m}$ in case of the defatted sample (DF) can be further ascribed to reduced grist stickiness which prevented agglomeration and coherent packing of fine particles. This phenomenon was similarly observed for defatted corn and oat flour after sieve and air classification, respectively $[54,55]$. Except for DF, highest mass fraction was mainly found in the medium particle range of $510-710$ or $710-1000 \mu \mathrm{m}$. Only small differences among
Fig. 3 Cumulative mass fraction (\%) of the mealworm grist produced by roller milling of the differently processed whole mealworm larvae samples determined via sieve analysis. Mesh sizes of $355,500,710,1000$, and $1400 \mu \mathrm{m}$ were used. Filled, cross-hatched and hatched pattern indicate fine $(<500 \mu \mathrm{m})$, medium $(500-1000 \mu \mathrm{m})$ and coarse $(>1000 \mu \mathrm{m})$ particle fractions, respectively

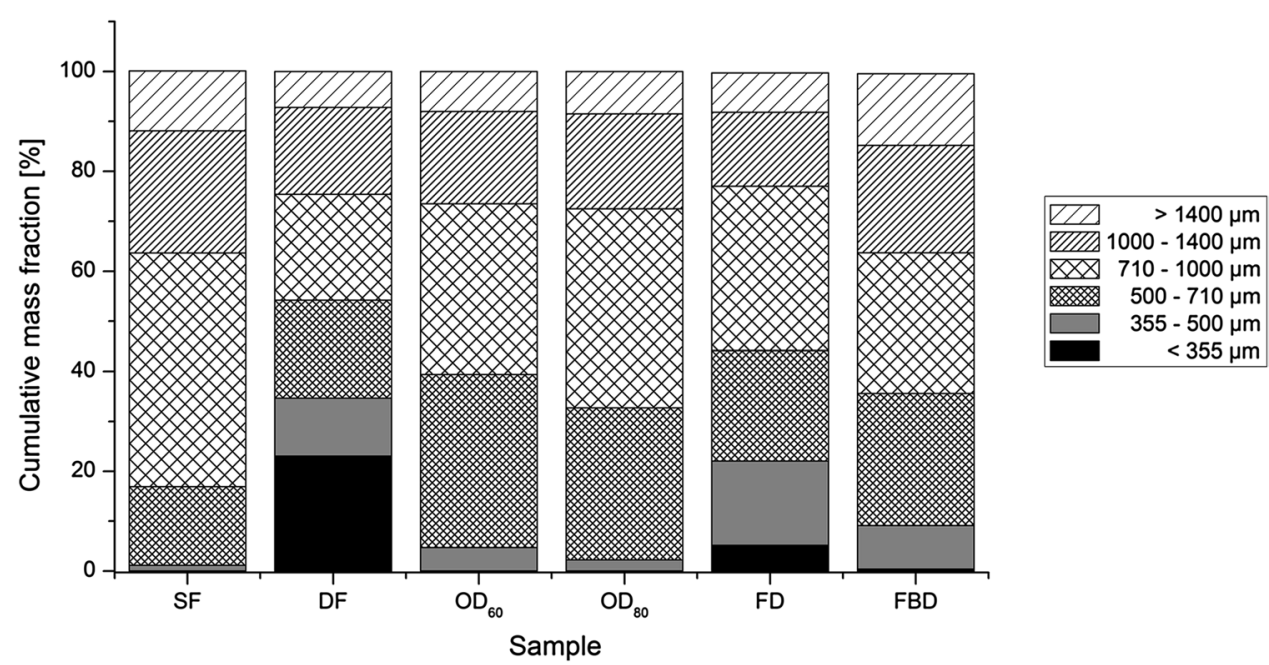


Table 2 Comparison of the mealworm grist mass fraction (\%) after milling of the differently pre-processed samples determined via sieve analysis

\begin{tabular}{|c|c|c|c|c|c|c|}
\hline \multirow[t]{2}{*}{ Sieving class $(\mu \mathrm{m})$} & \multicolumn{6}{|c|}{ Mass fraction (\%) } \\
\hline & SF & $\mathrm{DF}$ & $\mathrm{OD}_{60}$ & $\mathrm{OD}_{80}$ & FD & FBD \\
\hline$<355$ & $0.06 \pm 0.12^{\mathrm{a}}$ & $23.08 \pm 0.96^{\mathrm{c}}$ & $0.06 \pm 0.05^{\mathrm{a}}$ & $0.03 \pm 0.03^{\mathrm{a}}$ & $5.15 \pm 1.75^{\mathrm{b}}$ & $0.42 \pm 0.30^{\mathrm{a}}$ \\
\hline $355-500$ & $1.12 \pm 0.51^{\mathrm{a}}$ & $11.58 \pm 0.05^{\mathrm{d}}$ & $4.69 \pm 1.22^{\mathrm{b}}$ & $2.23 \pm 1.62^{\mathrm{a}}$ & $16.90 \pm 2.73^{\mathrm{e}}$ & $8.69 \pm 1.71^{\mathrm{c}}$ \\
\hline $500-710$ & $15.73 \pm 2.97^{\mathrm{a}}$ & $19.56 \pm 0.95^{\mathrm{ab}}$ & $34.64 \pm 2.83^{\mathrm{e}}$ & $30.46 \pm 3.02^{\mathrm{d}}$ & $22.10 \pm 2.06^{\mathrm{b}}$ & $26.46 \pm 1.94^{\mathrm{c}}$ \\
\hline $710-1000$ & $46.74 \pm 3.61^{\mathrm{e}}$ & $21.17 \pm 0.68^{\mathrm{a}}$ & $34.12 \pm 2.70^{c}$ & $39.80 \pm 3.19^{\mathrm{d}}$ & $32.88 \pm 3.10^{c}$ & $28.13 \pm 0.80^{\mathrm{b}}$ \\
\hline $1000-1400$ & $24.45 \pm 2.57^{\mathrm{d}}$ & $17.43 \pm 1.09^{\mathrm{ab}}$ & $18.48 \pm 0.99^{\mathrm{b}}$ & $18.99 \pm 1.64^{\mathrm{b}}$ & $14.78 \pm 1.95^{\mathrm{a}}$ & $21.52 \pm 0.88^{\mathrm{c}}$ \\
\hline$>1400$ & $12.02 \pm 2.61^{\mathrm{b}}$ & $7.19 \pm 0.09^{\mathrm{a}}$ & $8.02 \pm 0.66^{\mathrm{a}}$ & $8.48 \pm 2.11^{\mathrm{a}}$ & $7.93 \pm 0.82^{\mathrm{a}}$ & $14.34 \pm 1.18^{\mathrm{c}}$ \\
\hline
\end{tabular}

Values are presented as mean \pm SD of six-fold measurement. Different superscripts within one row indicate significant differences among the samples ( $p \leq 0.05$; one-way ANOVA, LSD post hoc test)

Table 3 Chemical composition (\% db) of larval fraction after milling and sieve classification of differently pre-processed mealworm larvae

\begin{tabular}{|c|c|c|c|c|c|c|}
\hline \multirow[t]{2}{*}{ Sample ID } & \multicolumn{6}{|c|}{ Composition (\%db) } \\
\hline & $<355 \mu \mathrm{m}$ & $355-500 \mu \mathrm{m}$ & $500-710 \mu \mathrm{m}$ & $710-1000 \mu \mathrm{m}$ & $1000-1400 \mu \mathrm{m}$ & $>1400 \mu \mathrm{m}$ \\
\hline \multicolumn{7}{|l|}{ SF } \\
\hline Crude protein & $56.84 \pm 0.33^{\mathrm{d}}$ & & & $55.12 \pm 0.57^{\mathrm{c}}$ & $53.36 \pm 0.38^{\mathrm{a}}$ & $54.10 \pm 0.69^{\mathrm{b}}$ \\
\hline Crude fat & $24.06 \pm 0.43^{\mathrm{a}}$ & & & $24.39 \pm 0.18^{\mathrm{a}}$ & $26.62 \pm 0.27^{\mathrm{c}}$ & $25.57 \pm 0.31^{\mathrm{b}}$ \\
\hline Chitin & $7.71 \pm 0.46^{\mathrm{a}}$ & & & $10.28 \pm 0.68^{b}$ & $11.88 \pm 1.33^{c}$ & $10.39 \pm 0.16^{\mathrm{b}}$ \\
\hline \multicolumn{7}{|l|}{ DF } \\
\hline Crude protein & $65.55 \pm 0.09^{c}$ & $66.47 \pm 0.09^{c}$ & $65.99 \pm 0.81^{\mathrm{c}}$ & $60.17 \pm 0.01^{\mathrm{a}}$ & $60.24 \pm 0.57^{\mathrm{a}}$ & $62.03 \pm 0.66^{\mathrm{b}}$ \\
\hline Crude fat & $11.65 \pm 0.17^{\mathrm{d}}$ & $9.04 \pm 0.06^{\mathrm{c}}$ & $8.45 \pm 0.03^{\mathrm{a}}$ & $8.79 \pm 0.02^{b}$ & $9.10 \pm 0.17^{\mathrm{c}}$ & $8.26 \pm 0.12^{\mathrm{a}}$ \\
\hline Chitin & $8.72 \pm 0.23^{\mathrm{a}}$ & $10.75 \pm 0.36^{\mathrm{bc}}$ & $10.33 \pm 0.44^{\mathrm{b}}$ & $12.04 \pm 0.66^{\mathrm{c}}$ & $13.53 \pm 1.20^{\mathrm{d}}$ & $11.64 \pm 0.22^{\mathrm{c}}$ \\
\hline \multicolumn{7}{|l|}{$\mathrm{OD}_{60}$} \\
\hline Crude protein & $53.39 \pm 1.78^{\mathrm{a}}$ & & $55.90 \pm 0.69^{d}$ & $54.77 \pm 1.17^{\mathrm{c}}$ & $53.55 \pm 1.11^{\mathrm{ab}}$ & $54.59 \pm 0.85^{\mathrm{bc}}$ \\
\hline Crude fat & $23.90 \pm 0.31^{\mathrm{c}}$ & & $22.99 \pm 0.38^{\mathrm{a}}$ & $23.34 \pm 0.23^{\mathrm{b}}$ & $24.93 \pm 0.20^{\mathrm{e}}$ & $24.52 \pm 0.25^{\mathrm{d}}$ \\
\hline Chitin & $10.60 \pm 0.00^{\mathrm{a}}$ & & $10.01 \pm 0.97^{\mathrm{a}}$ & $11.92 \pm 1.10^{\mathrm{a}}$ & $11.91 \pm 0.35^{\mathrm{a}}$ & $11.86 \pm 0.59^{\mathrm{a}}$ \\
\hline \multicolumn{7}{|l|}{$\mathrm{OD}_{80}$} \\
\hline Crude protein & $55.04 \pm 1.40^{\mathrm{a}}$ & & & $53.89 \pm 1.19^{\mathrm{a}}$ & $53.37 \pm 1.54^{\mathrm{a}}$ & $53.21 \pm 1.47^{\mathrm{a}}$ \\
\hline Crude fat & $22.88 \pm 0.82^{\mathrm{a}}$ & & & $24.44 \pm 0.41^{\mathrm{b}}$ & $25.50 \pm 0.47^{\mathrm{c}}$ & $25.69 \pm 0.25^{\mathrm{c}}$ \\
\hline Chitin & $10.54 \pm 1.51^{\mathrm{a}}$ & & & $10.23 \pm 0.69^{\mathrm{a}}$ & $9.91 \pm 0.40^{\mathrm{a}}$ & $10.98 \pm 0.91^{\mathrm{a}}$ \\
\hline \multicolumn{7}{|l|}{ FD } \\
\hline Crude protein & $55.05 \pm 1.07^{\mathrm{d}}$ & & $52.51 \pm 0.78^{a}$ & $53.45 \pm 1.03^{\mathrm{b}}$ & $53.75 \pm 0.86^{\mathrm{bc}}$ & $54.48 \pm 0.91^{\mathrm{cd}}$ \\
\hline Crude fat & $26.12 \pm 0.27^{\mathrm{e}}$ & & $24.12 \pm 0.18^{\mathrm{d}}$ & $23.40 \pm 0.23^{\mathrm{c}}$ & $21.35 \pm 0.13^{\mathrm{a}}$ & $21.78 \pm 0.17^{\mathrm{b}}$ \\
\hline Chitin & $3.60 \pm 0.65^{\mathrm{a}}$ & & $11.20 \pm 0.45^{\mathrm{b}}$ & $11.23 \pm 0.19^{\mathrm{b}}$ & $16.06 \pm 0.67^{\mathrm{d}}$ & $13.44 \pm 0.90^{\mathrm{c}}$ \\
\hline \multicolumn{7}{|l|}{ FBD } \\
\hline Crude protein & $58.24 \pm 0.13^{c}$ & & $56.61 \pm 0.36^{\mathrm{b}}$ & $55.95 \pm 0.59^{\mathrm{b}}$ & $54.57 \pm 0.65^{\mathrm{a}}$ & $53.75 \pm 0.48^{\mathrm{a}}$ \\
\hline Crude fat & $22.85 \pm 0.19^{\mathrm{b}}$ & & $21.70 \pm 0.11^{\mathrm{a}}$ & $22.32 \pm 0.34^{b}$ & $24.29 \pm 0.24^{c}$ & $26.15 \pm 0.85^{\mathrm{d}}$ \\
\hline Chitin & $8.10 \pm 0.72^{\mathrm{a}}$ & & $11.35 \pm 1.30^{\mathrm{b}}$ & $13.02 \pm 0.65^{\mathrm{c}}$ & $12.35 \pm 0.73^{\mathrm{bc}}$ & $12.46 \pm 0.87^{\mathrm{bc}}$ \\
\hline
\end{tabular}

Values are presented as mean \pm SD of at least triplicate measurement. Different superscripts within a row indicate significant differences of the respective component among the sieving fractions of one sample ( $p \leq 0.05$; one-way ANOVA, LSD post hoc test)

the samples were found in the sieving fraction $>1400 \mu \mathrm{m}$. This might be due to the presence of larvae which remains intact or were insufficiently disintegrated by one-step roller milling.

Chemical compositions in terms of crude protein, crude fat and chitin content of the sieving fractions are compiled in Table 3. The macro-nutrient distribution showed significant variations depending on particle class and pre-processing. Compositional ranges of 52.52-58.24, 21.35-26.62, 3.60-16.06, and $4.15-5.36 \% \mathrm{db}$ (data not shown) were determined for protein, fat, chitin, and ash content, respectively. Defatting prior to sieving (sample DF) led to the 
following span of components: $60.17-66.47 \% \mathrm{db}$ protein, $8.26-11.65 \% \mathrm{db}$ fat, $8.72-13.53 \% \mathrm{db}$ chitin, and $5.43-5.85 \% \mathrm{db}$ ash (data not shown).

The composition of the fractions revealed decreasing chitin content with decreasing particle size of the mealworm grist except for oven-dried samples. Lowest chitin concentrations $(3.60-8.72 \% \mathrm{db})$ were found in the small particle fraction of SF, DF, FD, and FBD, respectively, while chitin content of $\mathrm{OD}_{60}$ and $\mathrm{OD}_{80}$ showed no statistically significant difference throughout the sieving classes. Highest proportion of chitin was mainly observed in the range of $1000-1400 \mu \mathrm{m}$ indicating that roller milling of larvae led to preferential disintegration of the chitin exoskeleton into coarser particles. This might be due to its characteristic structure formed by helicoid bundles of chitin-protein fibrils (Bouligand structure) comparable to collagen or cellulose fibres [56]. Lower chitin content of the particle fraction $>1400 \mu \mathrm{m}$ can be ascribed to insufficiently ground or even intact larvae. Freeze-drying-resulting in highest porosity of the dried larvae-enhanced the effect of chitin separation as highest chitin concentration of $16.06 \% \mathrm{db}$ was found. The lower drying temperature and higher larval brittleness might have improved the disentanglement of chitin shell and adherent tissue.

Consequently, chitin depletion led to a statistically significant enrichment of protein in the aforementioned fine particle fractions. Similar trends of increasing protein content with decreasing particle size after milling have been reported for the fractionation of plant-based raw materials such as de-oiled rice bran [57], winter wheat flour [58] and distillers dried grains from yellow corn [59]. The particle fractions $<500 \mu \mathrm{m}$ of FBD and 355-500 $\mu \mathrm{m}$ of DF exhibited the highest protein contents of 58.2 and $66.5 \% \mathrm{db}$ representing an increase of protein concentration of about
4.9 and $5.4 \% \mathrm{db}$, respectively, in comparison to the initial protein content of the whole larvae $(53.26 \% \mathrm{db})$ and the defatted larvae $(61.06 \% \mathrm{db})$. The extent of protein enrichment found in this study is only limited compared to the increase of protein concentration observed in dry fractionated plant sources after sieve classification or single-pass air classification ranging from 5 to $40 \% \mathrm{db}$ [57-59] and $25-44 \% \mathrm{db}$ [30], respectively. The amount of protein recovered in the fine $(<500 \mu \mathrm{m})$, medium $(500-1000 \mu \mathrm{m})$, and coarse $(>1000 \mu \mathrm{m})$ mealworm grist fraction is illustrated in Fig. 4. In analogy to the distribution of the mass fraction (see Fig. 3), protein recovery was found to be highest in the medium particle fraction ranging between 42 and $72 \%$. Fine and coarse fractions show protein recoveries of $2.3-37.4 \%$ and $23.1-36.8 \%$. In general, the fine and the coarse fraction can be regarded as protein-rich and chitinrich, respectively.

In case of thermally dried samples $\left(\mathrm{SF}, \mathrm{OD}_{60}, \mathrm{OD}_{80}\right.$ and FDB), fat content in sized fractions showed an upper trend with increasing particle size while freeze-drying (FD) led to the reverse trend showing higher fat contents in the fine particle fractions. Insects store the majority of lipids in an organ called fat body which is distributed throughout the insect body, preferentially underneath the chitin exoskeleton [60]. Furthermore, lipids present only a small percentage of the total dry weight of the cuticle [61]. This may explain the low fat content in the coarse, chitin-rich fractions of FD. Application of thermal drying may have contributed to co-diffusion of melted fat from the inner tissue (fat body) to the chitin shell during water removal resulting in an increase in chitin-associated fat. Supercritical $\mathrm{CO}_{2}$ defatting of thermally dried larvae prior milling superimposed this heat-induced phenomenon. Highest fat concentration was found in the low-chitin, fine particle fraction
Fig. 4 Protein recovery (\%) depending on the particle size class of the mealworm grist produced by roller milling of the differently pre-processed whole mealworm larvae samples. Error bars indicate the cumulative SD of the protein recovery calculated using the SDs of the protein recoveries in the single sieving fraction

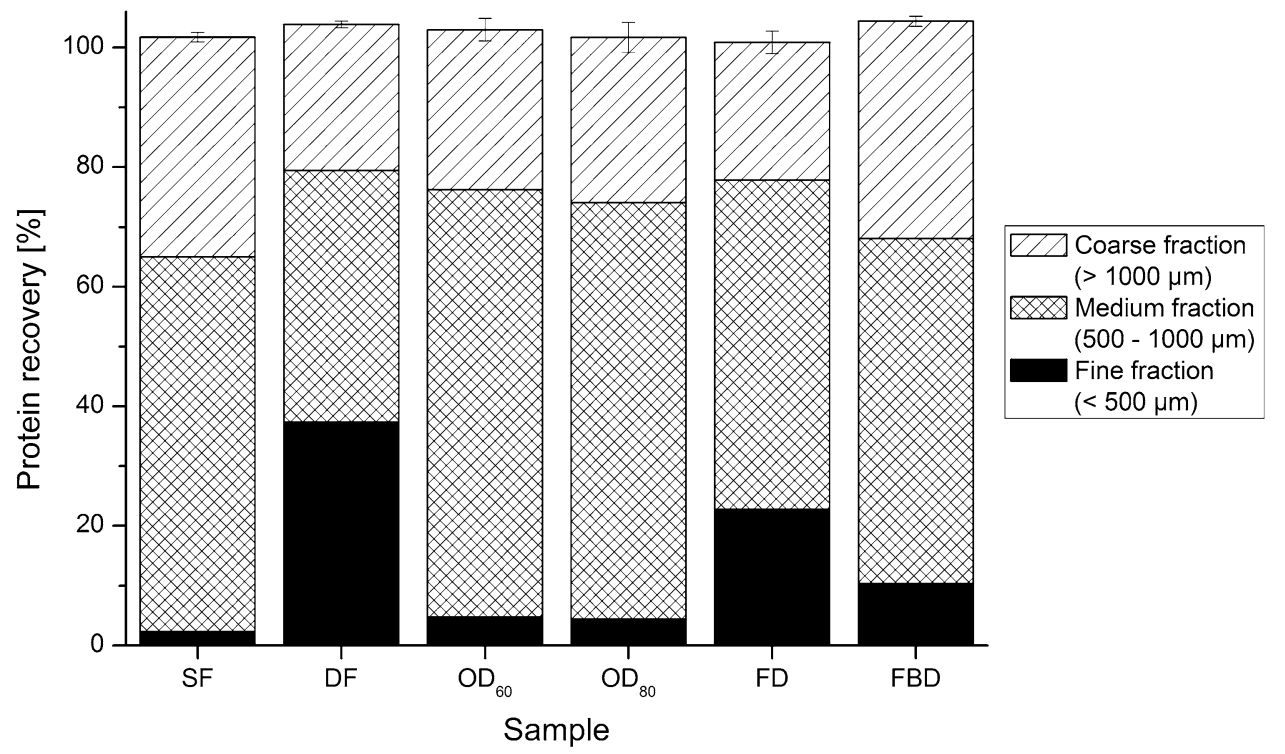


$(0-355 \mu \mathrm{m})$ of DF due to the better availability and extractability of the superficial, chitin-associated fat in comparison to the fat from inside the larvae requiring diffusive mass transfer [62].

\section{Conclusion}

Even though edible insects are often designated as a promising alternative to conventional protein sources for the inclusion in Western food and feed industry, fundamental knowledge about this novel raw material is still scarce. Next, to the lack of information regarding the food and feed safety status of edible insect or economic mass rearing techniques, studies broaching the issue of post-harvest and industrial-scale processing of edible insects or fractions thereof are required and will help to evaluate potential applications areas.

The present study aimed to investigate the impact of several post-harvest processing routes on the physico-chemical characteristics of mealworm larvae. For the first time, a dry fractionation approach based on size classification was investigated aiming to produce protein-enriched and differently composed fractions.

Physico-chemical properties of the dried larvae were found to be highly dependent on the applied pre-processing. Beside the colour and the dimensions, bulk material properties such as apparent density and hardness were significantly affected and led to different disintegration behaviour, thus, milling and separation properties. Thermal drying resulted in low mass fractions $(<10 \%)$ of fine particles from 0 to $500 \mu \mathrm{m}$ after milling. Processing steps preserving a porous-like larvae structure such as freeze-drying and defatting after drying induced a higher proportion of the fine particle fraction. Dry fractionation led to a variety of mealworm fractions with different chemical composition which could help to tailor nutritional and functional characteristics as ingredient in a complex food matrix. Protein enrichment of up to $5.4 \%$ to a maximum protein content of 58\% (0-500 $\mu \mathrm{m}, \mathrm{FDB})$ and $66 \%(355-500 \mu \mathrm{m}$, DF) could be achieved with this simple dry fractionation setup applied. The use of alternative separation techniques such as air classification or triboelectric separation might improve the dry fractionation ability of mealworms and enhance protein concentration or chitin depletion, respectively.

Dry fractionation of edible insects can become a viable alternative to conventional wet fractionation approaches. Therefore, the optimization of the chitin separation as well as the investigation of the functional properties of the resulting fractions have to be tackled in further studies as they represent key factors determining the applicability of dry fractionated insects.
Acknowledgements Open access funding provided by University of Natural Resources and Life Sciences Vienna (BOKU).

\section{Compliance with ethical standards}

Conflict of interest The authors have declared no conflicts of interest.

Compliance with ethics requirements Corresponding to the Austrian (BGB1. I Nr. 169/1999) and European law (Directive 2010/63/ $\mathrm{EU})$ on the protection of animals used for scientific purposes, this article does not contain studies with animal subjects as experiments with insects or invertebrates are not classified as animal experiments. Nevertheless, animal subjects used in this study were anesthetized in order to consider animal welfare.

Open Access This article is distributed under the terms of the Creative Commons Attribution 4.0 International License (http:// creativecommons.org/licenses/by/4.0/), which permits unrestricted use, distribution, and reproduction in any medium, provided you give appropriate credit to the original author(s) and the source, provide a link to the Creative Commons license, and indicate if changes were made.

\section{References}

1. van Huis A (2013) Potential of insects as food and feed in assuring food security. Annu Rev Entomol 58:563-583

2. FAO (2013) Edible insects-future prospects for food and feed security. FAO forestry paper, vol 171. FAO, Rome

3. Makkar HPS, Tran G, Heuzé V, Ankers P (2014) State-of-the-art on use of insects as animal feed. Anim Feed Sci Technol 197:133. doi:10.1016/j.anifeedsci.2014.07.008

4. Smetana S, Palanisamy M, Mathys A, Heinz V (2016) Sustainability of insect use for feed and food: life cycle assessment perspective. J Clean Prod 137:741-751. doi:10.1016/j. jclepro.2016.07.148

5. Diener S, Studt Solano NM, Roa Gutiérrez F, Zurbrügg C, Tockner K (2011) Biological treatment of municipal organic waste using black soldier fly larvae. Waste Biomass Valoriz 2(4):357363. doi:10.1007/s12649-011-9079-1

6. Rumpold BA, Schlüter OK (2013) Nutritional composition and safety aspects of edible insects. Mol Nutr Food Res 57(5):802823. doi: $10.1002 / \mathrm{mnfr} .201200735$

7. Nowak V, Persijn D, Rittenschober D, Charrondiere UR (2016) Review of food composition data for edible insects. Food Chem 193:39-46. doi:10.1016/j.foodchem.2014.10.114

8. Osimani A, Garofalo C, Milanović V, Taccari M, Cardinali F, Aquilanti L, Pasquini M, Mozzon M, Raffaelli N, Ruschioni S, Riolo P, Isidoro N, Clementi F (2016) Insight into the proximate composition and microbial diversity of edible insects marketed in the European Union. Eur Food Res Technol. doi:10.1007/ s00217-016-2828-4

9. Rumpold BA, Schlüter OK (2013) Potential and challenges of insects as an innovative source for food and feed production. Innov Food Sci Emerg Technol 17:1-11. doi:10.1016/j. ifset.2012.11.005

10. EFSA Scientific Committee (2015) Scientific opinion on a risk profile related to production andconsumption of insects as food and feed. EFSA J 13(10):4257.doi:10.2903/j.efsa.2015.4257

11. Cortez Ortiz J, Torres Ruiz A, Morales-Ramos JA, Thomas M, Rojas M, Tomerlin J (2016) Insect mass production technologies. In: Dossey AT, Morales-Ramos JA, Guadalupe Rojas M (eds) 
Insects as sustainable food ingredients-production, processing and food applications. Academic Press, London, pp 153-200

12. Finke MD (2015) Complete nutrient content of four species of commercially available feeder insects fed enhanced diets during growth. Zoo Biol 34(6):554-564. doi:10.1002/zoo.21246

13. Barker D, Fitzpatrick MP, Dierenfeld ES (1998) Nutrient composition of selected whole invertebrates. Zoo Biol 17(2):123-134. doi:10.1002/ (SICI) 1098-2361(1998)17:2<123:AID-ZOO7>3.0.CO;2-B

14. Bußler S, Rumpold BA, Fröhling A, Jander E, Rawel HM, Schlüter OK (2016) Cold atmospheric pressure plasma processing of insect flour from Tenebrio molitor: impact on microbial load and quality attributes in comparison to dry heat treatment. Innov Food Sci Emerg Technol 36:277-286. doi:10.1016/j. ifset.2016.07.002

15. Bußler S, Rumpold BA, Jander E, Rawel HM, Schlüter OK (2016) Recovery and techno-functionality of flours and proteins from two edible insect species: meal worm (Tenebrio molitor) and black soldier fly (Hermetia illucens) larvae. Heliyon 2(12):e00218. doi:10.1016/j.heliyon.2016.e00218

16. Zhao X, Vázquez-Gutiérrez JL, Johansson DP, Landberg R, Langton M (2016) Yellow mealworm protein for food purposesextraction and functional properties. PLoS One 11(2):e0147791. doi:10.1371/journal.pone.0147791

17. Xing-Qian Y, Dong-Hong L, Cui H (2001) Some factors' effects on the solubility of protein from yellow mealworm (Tenebrio molitor L) larvae. J Zhejiang Univ Sci 2(4):436-438. doi:10.1007/bf02840562

18. Hartmann C, Shi J, Giusto A, Siegrist M (2015) The psychology of eating insects: a cross-cultural comparison between Germany and China. Food Qual Prefer 44:148-156. doi:10.1016/j. foodqual.2015.04.013

19. Schösler H, Boer Jd, Boersema JJ (2012) Can we cut out the meat of the dish? Constructing consumer-oriented pathways towards meat substitution. Appetite 58(1):39-47. doi:10.1016/j. appet.2011.09.009

20. Tan HSG, Fischer ARH, Tinchan P, Stieger M, Steenbekkers LPA, van Trijp HCM (2015) Insects as food: exploring cultural exposure and individual experience as determinants of acceptance. Food Qual Prefer 42:78-89. doi:10.1016/j. foodqual.2015.01.013

21. Balzan S, Fasolato L, Maniero S, Novelli E (2016) Edible insects and young adults in a north-east Italian city an exploratory study. Br Food J 118(2):318-326. doi:10.1108/BFJ-04-2015-0156

22. SKLM (2016) Sicherheitsaspekte bei der Herstellung von Lebensmitteln und Lebensmittelinhaltsstoffen aus Insekten. Bonn

23. Schutyser MAI, van der Goot AJ (2011) The potential of dry fractionation processes for sustainable plant protein production. Trends Food Sci Technol 22(4):154-164. doi:10.1016/j. tifs.2010.11.006

24. Yi L, Lakemond CMM, Sagis LMC, Eisner-Schadler V, van Huis A, van Boekel MAJS (2013) Extraction and characterisation of protein fractions from five insect species. Food Chem 141(4):3341-3348. doi:10.1016/j.foodchem.2013.05.115

25. Ozimek L, Sauer WC, Kozikowski V, Ryan J, Jørgensen H, Jelen $\mathrm{P}$ (1985) Nutritive value of protein extracted from honey bees. J Food Sci 50(5):1327-1329

26. Ryan JK, Jelen P, Sauer WC (1983) Alkaline extraction of protein from spent honey bees. J Food Sci 48(3):886-896. doi:10.1111/j.1365-2621.1983.tb14923.x

27. Del Valle FR, Mena MH, Bourges H (1982) An investigation into insect protein. J Food Process Preserv 6(2):99-110. doi:10.1111/j.1745-4549.1982.tb00645.x

28. Tabtabaei S, Vitelli M, Rajabzadeh AR, Legge RL (2017) Analysis of protein enrichment during single- and multi-stage tribo-electrostatic bioseparation processes for dry fractionation of legume flour. Sep Purif Technol 176:48-58. doi:10.1016/j. seppur.2016.11.050

29. Pelgrom PJM, Vissers AM, Boom RM, Schutyser MAI (2013) Dry fractionation for production of functional pea protein concentrates. Food Res Int 53(1):232-239. doi:10.1016/j. foodres.2013.05.004

30. Tyler RT, Youngs CG, Sosulski FW (1981) Air classification of legumes. I. Separation efficiency, yield, and composition of the starch and protein fractions. Cereal Chem 58(2):144-148

31. Van Emden H (2013) Handbook of agricultural entomology. Wiley, Oxford

32. Laskowski J, Lysiak G (1999) Use of compression behaviour of legume seeds in view of impact grinding prediction. Powder Technol 105(1-3):83-88. doi:10.1016/ S0032-5910(99)00121-7

33. Fang C, Campbell GM (2003) On predicting roller milling performance V: effect of moisture content on the particle size distribution from first break milling of wheat. J Cereal Sci 37(1):3141. doi: $10.1006 /$ jcrs.2002.0476

34. Ruttarattanamongkol K, Siebenhandl-Ehn S, Schreiner M, Petrasch AM (2014) Pilot-scale supercritical carbon dioxide extraction, physico-chemical properties and profile characterization of Moringa oleifera seed oil in comparison with conventional extraction methods. Ind Crops Prod 58:68-77. doi:10.1016/j. indcrop.2014.03.020

35. Purschke B, Stegmann T, Schreiner M, Jäger H (2017) Pilot-scale supercritical CO2 extraction of edible insect oil from Tenebrio molitor L. larvae-Influence of extraction conditions on kinetics, defatting performance and compositional properties. Eur J Lipid Sci Technol 119(2):1-12. doi:10.1002/ejlt.201600134

36. ICC (1998) Determination of the particle size of milling products using sieve analysis, ICC Recomendation No. 207. ICC Standard methods

37. AOAC (2002) Official methods of analysis, vol 2, 17th edn. Association of Official Analytical Chemists, Gaithersburg

38. ICC (1984) Cereals and cereal products-Determination of total fat content, ICC Recomendation No. 136. ICC Standard methods

39. Daum G (2005) Aerobe Deproteinierung von CrustaceaenAbfällen zur Gewinnung von Chitin mittels proteolytischer Mikroorganismen. Universität Hamburg, Hamburg

40. No HK, Meyers SP (1997) Preparation of chitin and chitosan. In: Muzzarelli RAA, Peter MG (eds) Chitin Handbook. Atec, Grottamare, pp 475-489

41. Finke MD (2002) Complete nutrient composition of commercially raised invertebrates used as food for insectivores. Zoo Biol 21(3):269-285. doi:10.1002/zoo.10031

42. Azzollini D, Derossi A, Severini C (2016) Understanding the drying kinetic and hygroscopic behaviour of larvae of yellow mealworm (Tenebrio molitor) and the effects on their quality. $\mathbf{J}$ Insects Food Feed 2(4):233-243

43. Adekunte AO, Tiwari BK, Cullen PJ, Scannell AGM, O’Donnell CP (2010) Effect of sonication on colour, ascorbic acid and yeast inactivation in tomato juice. Food Chem 122(3):500-507. doi:10.1016/j.foodchem.2010.01.026

44. Verhaeghe T, Vlaemynck G, De Block J, Van Weyenberg S, Hendrickx M (2016) Thermal inactivation kinetics of proteases and polyphenoloxidase in brown shrimp (Crangon crangon). Food Chemistry 197(Part A):641-647. doi:10.1016/j. foodchem.2015.11.024

45. Jeon Y-H, Son Y-J, Kim S-H, Yun E-Y, Kang H-J, Hwang I-K (2016) Physicochemical properties and oxidative stabilities of mealworm (Tenebrio molitor) oils under different roasting conditions. Food Sci Biotechnol 25(1):105-110. doi:10.1007/ s10068-016-0015-9

46. Oikonomopoulou VP, Krokida MK, Karathanos VT (2011) The influence of freeze drying conditions on microstructural changes 
of food products. Procedia Food Sci 1:647-654. doi:10.1016/j. profoo.2011.09.097

47. Mayor L, Sereno AM (2004) Modelling shrinkage during convective drying of food materials: a review. J Food Eng 61(3):373-386. doi:10.1016/S0260-8774(03)00144-4

48. Prachayawarakorn S, Soponronnarit S, Wetchacama S, Jaisut D (2002) Desorption isotherms and drying characteristics of shrimp in superheated steam and hot air. Drying Technol 20(3):669-684. doi:10.1081/DRT-120002823

49. Hosseinpour S, Rafiee S, Mohtasebi SS (2011) Application of image processing to analyze shrinkage and shape changes of shrimp batch during drying. Drying Technol 29(12):1416-1438. doi:10.1080/07373937.2011.587620

50. Brown ZK (2010) The drying of foods using supercritical carbon dioxide. University of Birmingham, Birmingham

51. Kotwaliwale N, Bakane P, Verma A (2007) Changes in textural and optical properties of oyster mushroom during hot air drying. J Food Eng 78(4):1207-1211. doi:10.1016/j. jfoodeng.2005.12.033

52. Blandino M, Mancini MC, Peila A, Rolle L, Vanara F, Reyneri A (2010) Determination of maize kernel hardness: comparison of different laboratory tests to predict dry-milling performance. J Sci Food Agric 90(11):1870-1878

53. Pomeranz Y, Czuchajowska Z, Martin C, Lai F (1985) Determination of corn hardness by the Stenvert hardness tester. Cereal Chem 62(2):108-112

54. Pomeranz Y, Czuchajowska Z, Lai F (1986) Gross composition of coarse and fine fractions of small corn samples ground on the Stenvert hardness tester. Cereal Chem 63:22-26

55. Sibakov J, Myllymäki O, Holopainen U, Kaukovirta-Norja A, Hietaniemi V, Pihlava JM, Poutanen K, Lehtinen P (2011) Lipid removal enhances separation of oat grain cell wall material from starch and protein. J Cereal Sci 54(1):104-109. doi:10.1016/j. jcs.2011.04.003

56. Chen P-Y, Lin AY-M, McKittrick J, Meyers MA (2008) Structure and mechanical properties of crab exoskeletons. Acta Biomater 4(3):587-596. doi:10.1016/j.actbio.2007.12.010

57. Jayadeep A, Singh V, Sathyendra Rao BV, Srinivas A, Ali SZ (2009) Effect of physical processing of commercial de-oiled rice bran on particle size distribution, and content of chemical and bio-functional components. Food Bioprocess Technol 2(1):5767. doi:10.1007/s11947-008-0094-6

58. Tóth Á, Prokisch J, Sipos P, Széles É, Mars É, Győri Z (2006) Effects of particle size on the quality of winter wheat flour, with a special focus on macro- and microelement concentration. Commun Soil Sci Plant Anal 37(15-20):2659-2672. doi:10.1080/00103620600823117

59. Liu K (2008) Particle size distribution of distillers dried grains with solubles (DDGS) and relationships to compositional and color properties. Biores Technol 99(17):8421-8428. doi:10.1016/j.biortech.2008.02.060

60. Arrese EL, Soulages JL (2010) Insect fat body: energy, metabolism, and regulation. Annu Rev Entomol 55:207-225. doi:10.1146/annurev-ento-112408-085356

61. Prakash M (2008) Insect Biochemistry, vol 1. Discovery Publishing House, Dehli

62. Valle JMD, De La Fuente JC (2006) Supercritical $\mathrm{CO}_{2}$ extraction of oilseeds: review of kinetic and equilibrium models. Crit Rev Food Sci Nutr 46(2):131-160. doi:10.1080/10408390500526514 